\title{
高速液体クロマトグラフィーによるアプロチニン製剤の品質比較
}

\author{
松本直人，大島和夫，黒澤嘉幸 \\ 防衛医科大学校病院薬剤部*
}

\section{Quality Testing for Aprotinin Preparation by High-Performance Liquid Chromatography}

\author{
NaOto Matsumoto, Kazuo Ohsima, Yoshiyuki KuRosawa \\ Department of Pharmacy, National Defense Medical College Hospital*
}

(Received May 20, 1987)

\begin{abstract}
The analytical method for aprotinin preparation has been established using reversed phase high performance liquid chromatography, and the characteristics of the four contaminating unknown compounds in this preparation were studied. Aprotinin and the four contaminants were separated by using $\mathrm{C} 18$ column (CHEMCOSORB 5-ODS-H) and $13 \%$ acetonitrile containing 0.1 $\mathrm{M}$ potassium dihydrogenphosphate adjusted to $\mathrm{pH} 3.0$ with phosphoric acid as a mobile phase, or by using a $\mathrm{C} 4$ column (CHEMCOSORB $300-7 \mathrm{C} 4$ ) and $10 \%$ acetonitrile solution containing the same phosphate buffer as the mobile phase.

Five commercially available aprotinin injection forms were found to be composed of aprotinin and identical ratios of the four contaminants. In addition, the four contaminants had weaker inhibitory activity than aprotinin. These four contaminants were considered to be originated from aprotinin as their amino acid compositions of these contaminants were the same as that of aprotinin. Therefore, the production of these four contaminants may occur through an irreversible or extremely biased equilibrium process.
\end{abstract}

Keywords - aprotinin; commercial aprotinin injection; contaminant; peptide; pharmaceutical test; proteolytic enzyme inhibitor; reversed phase high-performance liquid chromatography

緒

\section{言}

蛋白分解酵素阻害作用を有するアプロチニンは，16種 のアミノ酸総計58個が鎖状に結合した分子量 6,512 のポ リペプチドで, 臨床上, 注射剤として急性膵炎, ショッ ク等の治療に用いられている.

アプロチニンは, 健康な牛肺臟から抽出, 精製される が，その精製技術により品質に差異が生じたり，不純物 の混入も考兄られる. 高杉ら ${ }^{11}$ は, その注射剤としての 薬剤学的評価を行い, 製造メーカーにより品質仼差異が 生じたと指摘している.

今回著者らは, アプロチニンの逆相HPLCのイソクラ ティク溶出法による分析法の確立を試み, 市販注射中に

* 埼玉県所沢市並木 3-2；3-2, Namiki, Tokorozawa-shi, Saitama, 359 Japan
含まれるアプロチニン様未知物質についてクロマトグラ フィー的検討を行った.

\section{実 跧 の 部}

\section{1. 試蒌及び試料}

アセトニトリルは HPLC 用 (関東化学), その他はす ベて特級試薬を用いた.アプロチニン注射剤は，50,000 単位の 5 社製品を用い, 製造番号は, A 社 (Lot No. Y 322)， B 社 (Lot No. R020)， C 社 (Lot No.4B179)，D 社 (Lot No. 4Y8140), E 社 (Lot No. 234050) のもの を用いた。

\section{2. 装 $\mathrm{E}$}

HPLC装置は, ALC/GPC 206型 $(6,000$ A ゚ンプ, U6 $\mathrm{K}$ インジェクター, 441ディテクター, 730データモジュ ール, 660 グラジェントプログラマー)（ウォーターズ 社) を用いた. カラムは, ケムコソルブ 5-ODS-H (4.6 


\section{Trypsin $0.1 \mathrm{~m} \ell$}

$(0.1 \mathrm{mg} / \mathrm{m} \ell$ in $0.001 \mathrm{NHCl})$

$0.2 \mathrm{M}$ Triethanolamine $-\mathrm{HCl}$

Buffer PH7.8

Inhibitor

$0.1 \mathrm{ml}$

$(0.02 \mathrm{mg} / \mathrm{m} \ell)$

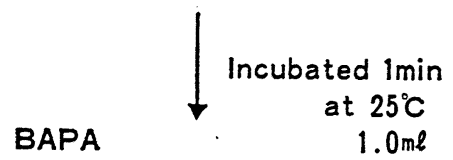

$(0.5 \mathrm{mg} / \mathrm{ml})$

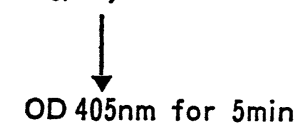

Chart 1. Assay of Aprotinin and Unknown Fractions

BAPA ( ${ }^{\alpha}$-benzoyl-L-arginine-pnitroanilide)

I.D. $\times 150 \mathrm{~mm})$ とケムコソルブ 300-7C4 (4.6 I.D. $\times$ $150 \mathrm{~mm}$ )（ケムコ社）を用いた。 アミノ酸分析装置は, 日立 835 型を用い，発色はニンヒドリンで行った。加水 分解は $6 \mathrm{~N}$ 塩酸で封管中 24 時間行った.

\section{3. 阻㝘活性の測定}

阻害活性の測定は, Kassel ら2) の方法に準じて行っ た (Chart 1).

\section{4. 蛋白定量}

Lowry-Folin 法3)により行い，検量線は Bovine Serum Albumin を用いた。

\section{5. アプロチニンおよび不純物の分取}

フプロチニン 3,000 単位を，ケムコソルブ 300-7C4 カ ラムに注入し，各分画を分取した. 脱塩はケムコソルブ 5-ODS-H カラムを用い，0.1\%トリフルオロ眽酸ーアセ トニトリルのグラジェント溶出法（アセトニトリル $0 \rightarrow$ $20 \% ， 5$ 分間，リニアグラジェント，試料注入量 $6 \mathrm{ml}$ ) で行い, 溶出液を遠ェバポレーターで濃縮し，トリフ ルオロ酶酸を除去した。

\section{結果及び考察}

\section{HPLC 条件の検討}

シリカゲル基体の逆相系カラムを用いて蛋白質, ペプ チドを分析するとき，シルカゲル表面のシラノール基に よる吸着, ピークのテーリング現象が問題》)となる。こ れらを低減するには移動相に塩, 高級アミン, 対イオ
ン4)の添加で解決できる，そこで，アプロチニンの逆相 HPLCによる分析法を確立するにあたり，その条件を考 慮し, カラムにオクタデシルシラン（C18）とブチルシ ラン (C 4) 充填カラムを用い, 移動相条件を種々検討し た。

塩基性の高い蛋白質やペプチドの分析では, 移動相の $\mathrm{pH}$ を酸性側侸定することが望ましい5)ことから，移 動相には 0.1M リン酸緩衝液 ( $\mathrm{pH} 3.0), 0.1 \mathrm{M} ト$ リチチ ルアミンーリン酸 $(\mathrm{pH} 3.0) ， 0.1 \%$ リフルオロ酢酸等 を含む 3 種のアセトニトリル水溶液のイソクラティック 溶出法で検討したところ，いずれのカラムでも，0.1Mリ 酸緩衝液を含むアセトニトリル水溶液が, 最もピーク のテーリングが少なく，各成分の分離も良好であった。 その溶出パターンは, Gazdag ら²) の結果と同様で, ア プロチニンの溶出位置より早い時間に 4 つの未知成分が 溶出した (Fig. 1).

一般に, 逆相 HPLC のイソクラティック溶出法で蛋 白質やペプチドを分析する場合，移動相中の有機溶媒量

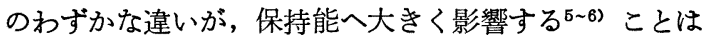
知られている。 そこで, 本実験もC18 とC4 カラムにお いて，アプロチニンの保持能に及ぼす影響について検討 したところ，いずれのカラムにおいてもアセトニトリル 量と保持能の対数は直線性を示したが，その傾きは，C 18 カラムで-0.414, C 4 カラムで -0.200 であり, C 18 カラムが大きく影響を受けることがわかった (Fig. 2).

カラムからの回収率は, アプロチニン 1,000 単位注入 時，C18カラムで $93.5 \% ， \mathrm{C} 4$ カラムで $95.8 \%$ で，とも 飞高回収率を示した。

Fig. 1 において，2つのクロマトグラムを比較する と，C18カラムが理論段数において優れているが，その 反面，保持能がアセトニトリル量に大きく影響を受ける こと，分取するために大量注入した場合ピークのテーリ ングがみられることから，以後の実験はC 4 カラムを用 いて行った.

定量は, UV 214nm のピーク面積值の絶対検量線法で 行った. Table 1 に, アプロチニン 100 単位注入時の再 現性について示したが，アプロチニンと 4 つの未知物質 の再現性は，C.V.值 $1.18-2.93 \%$ と良好であった。検 量線は, 10〜1,000 単位の間で良好な直線性を示した (Table 2).

\section{2. 市販アプロチニン注射刘の分析}

Fig. 3 亿市販アプロチニン注射剤 5 製品の 100 単位注 入時のクロマトグラムを示した， $\mathrm{E}$ 社は，先端に添加剤 のベンジルアルュールが溶出する以外, 各製品とも Gazdag ら6) の溶出パターンと同様で, アプロチニンの 

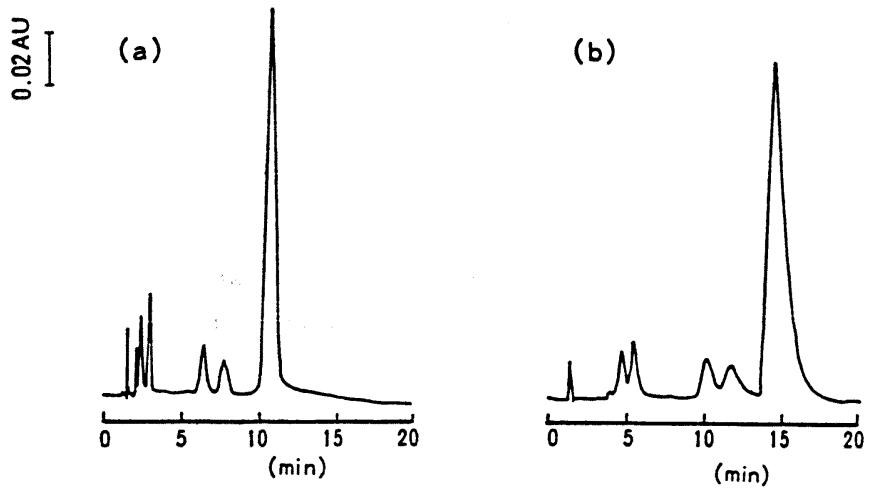

Fig. 1. Chromatograms of Aprotinin Preparation (Injection) in C18 Column (a) and C4 Column (b)

HPLC condition: column, (a): CHEMCOSORB 5ODS-H (4.6 I.D. $\times 150 \mathrm{~mm}$ ), (b): CHEMCOSORB 3007C4 (4.6 I.D. $\times 150 \mathrm{~mm}$ ); mobile phase, $13 \%$ acetonitrilewater $+0.1 \mathrm{M}$ potassium dihydrogenphosphate, $\mathrm{pH}$ adjusted to 3.0 with phosporic acid (C18 column), 10\% acetonitrile-water $+0.1 \mathrm{M}$ potassium dihydrogenphosphate, $\mathrm{pH}$ adjusted to 3.0 with phosphoric acid (C4 column); column temperature, ambient; flow rate, $1.0 \mathrm{ml} / \mathrm{min}$; detection, UV $214 \mathrm{~nm}, 0.2$ aufs; sample size, 100 units as aprotinin

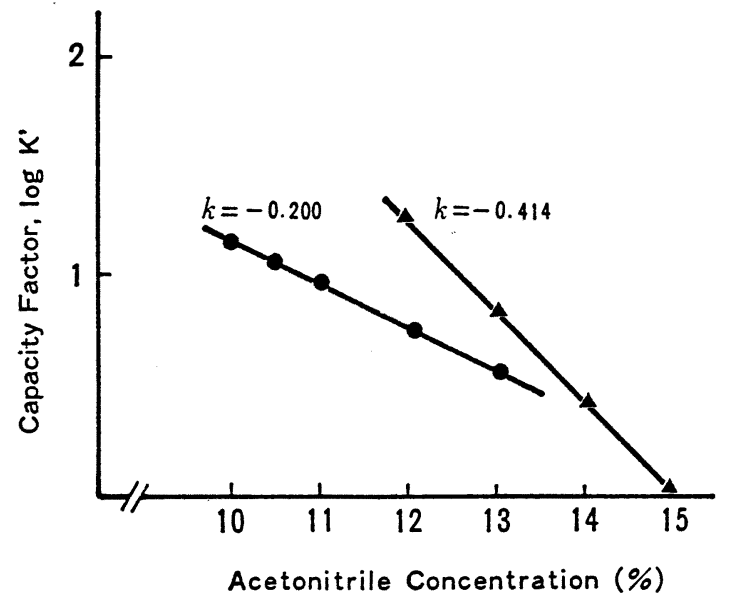

Fig. 2. Effect of Acetonitrile Concentration on Capacity Factor ( $\mathrm{K}^{\prime}$ ) of Aprotinin

- - : C4 column, - $\mathbf{\Delta - ~ : ~ C 1 8 ~ c o l u m n ~}$

HPLC condition were the same as described in Fig. 1 in the presense of $0.1 \mathrm{M}$ potassium dihydrogenphosphate

大きなピークが溶出する以前に 4 つの小さなピークが溶 出し, その保持時間は各製品とも一致した. また, C 18 カラムにおいても 4 つの小さなピークの保持時間が各製
Table 1. Reproducibility Analysis of Aprotinin and Unknown Compound

\begin{tabular}{cccccc}
\hline \hline $\begin{array}{c}\text { Injection } \\
\text { No. }\end{array}$ & \multicolumn{5}{c}{ Peak Area Ratio } \\
\cline { 3 - 5 } & 1 & 2 & 3 & 4 & 5 \\
1 & 1754 & 2436 & 2088 & 1926 & $\begin{array}{c}\text { Fraction No. } \\
\text { (aprotinin) }\end{array}$ \\
2 & 1715556 \\
3 & 1749 & 2555 & 1985 & 2029 & 31258 \\
4 & 1715 & 2463 & 2025 & 1918 & 30165 \\
5 & 1755 & 2451 & 2022 & 2031 & 29670 \\
$\bar{\chi}$ & 1738 & 2484 & 2017 & 1967 & 30723 \\
C. V. $(\%)$ & 1.18 & 2.00 & 2.36 & 2.93 & 2.55 \\
\hline
\end{tabular}

HPLC condition were the same as described in Fig. 1 using CHEMCOSORB 300-7C4

品間で一致することから，アプロチニン以外の 4 つピー クは各製品間とも同じ成分と考えられた．以後，この分 析条件で溶出してくるピークを溶出順序ごとに $1 \sim 5$ の 番号で示す.

Table 3 に, ベンジルアルュールを除き, 溶出してく るピークの全面積を $100 \%$ としたときの各分画の面積百 分率を示したが，いずれの製品もアプロチニン含量比率 には大きな違いはなく70\%前後で，4つの分画含量にも 
Table 2. Calibration Curves for Aprotinin and Unknown Compound

\begin{tabular}{cccccc}
\hline \hline & \multicolumn{5}{c}{ Fraction No. } \\
& 1 & 2 & 3 & 4 & 5 \\
Slope & 17.0 & 24.4 & 19.8 & 19.7 & 323 \\
Intercept & 5 & 22 & -65 & -38 & -1498 \\
$r$ & 0.995 & 0.998 & 0.999 & 0.997 & 0.999 \\
\hline
\end{tabular}

Aprotinin injection $10-1000$ units

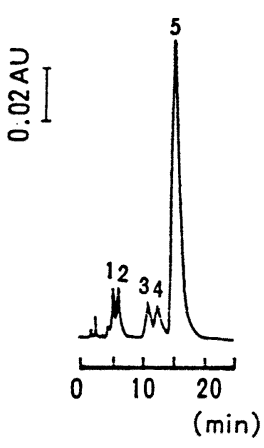

A

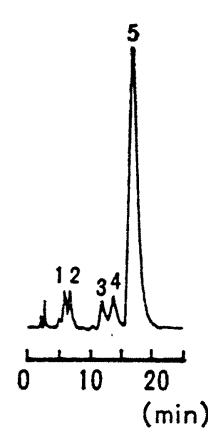

B

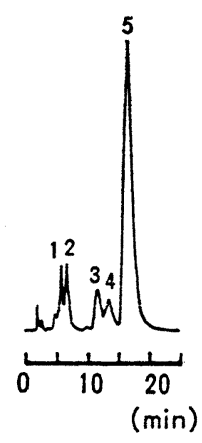

C.

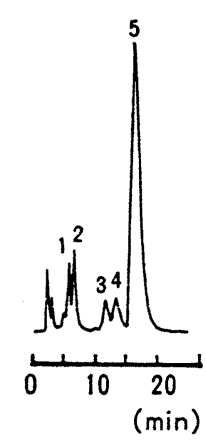

D

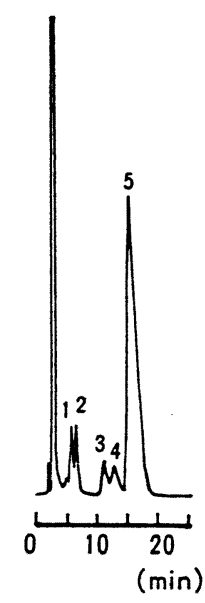

E

Fig. 3. Chromatograms of Five Commercial Aprotinin Injection HPLC condition were the same as described in Fig. 1 in the presense of CHEMCOSORB 300-7C4

Table 3. Composition of Aprotinin and Unknown Fractions in the Five Commercial Injections

\begin{tabular}{|c|c|c|c|c|c|c|}
\hline $\begin{array}{c}\text { Fraction } \\
\text { com. }\end{array}$ & 1 & 2 & 3 & 4 & 5 & Total of \\
\hline A & 4.0 & 5.4 & 5.3 & 5.9 & 77.7 & 98.3 \\
\hline B & 3.6 & 4.5 & 4.1 & 7.0 & 77.9 & 97.1 \\
\hline C & 5.1 & 6.5 & 6.2 & 6.3 & 70.6 & 94.7 \\
\hline D & 4.8 & 7.6 & 4.5 & 6.2 & 67.7 & 90.8 \\
\hline E & 5.5 & 6.9 & 4.4 & 4.8 & 75.8 & 97.4 \\
\hline
\end{tabular}

Each value represents the mean for three separate experiment.

Except for benzylalcohol peak in $\mathrm{E}$ commercial preparation.

大きな違いはなかった。

\section{3. 各分画の比較}

アプロチニン以外の 4 つの分画が，まったくの異種化
合物であるならば，その製剂の抽出，精製方法に改良が 必要と考学られる。そこで5つの分画を分取し，阻害活

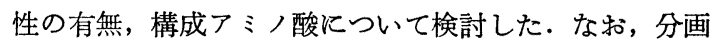
1 から 4 は各製品間に拈いて子同一成分と考兄られたた め, 今回は $\mathrm{A}$ 社の製品の分画 1 から 5 について行った.

Table 4 に, 各分画の阻害活性について示した. 蛋白 量 $20 \mu \mathrm{g} / \mathrm{ml}$ 飞揃兄た各分画の阻害率は, アプロチニン 分画が $67.6 \%$ と大きく 1 から 4 の分画はアプロチニン よりやや小さいが，いずれも阻害活性を有することが認 められた。

ゲルろ過法では各分画の分離はできない8ことと， Lowry-Folin法で定量できること, 阻害活性を有するこ とから， 1 から 4 の分画はアプロチニンと分子量が近い 類似のポリペプチドと推測できる. 次に, 各分画のアミ ノ酸組成を比較した. Table 5 亿各分画のアミノ酸組成 について示した. 分画 1 から 4 までのアミノ酸組成は, アプロチニンと同じであり，文献值2) と一致したことか 
Table 4. Activity of Aprotinin and Unknown Fractions

\begin{tabular}{c|c}
\hline Fraction No. & Inhibitory Activity (\%) \\
\hline 1 & 57.6 \\
2 & 57.7 \\
3 & 62.7 \\
4 & 60.8 \\
5 & 67.6 \\
\hline
\end{tabular}

Each value represents the mean for six separate experiment

ら，異種ポリペプチドであることは否定された．

アプロチニンは, 中性状態に扎いて二量体を形成9す ることから，1から 4 の分画は, 結合部位がわずかに異 なる二量体と考えられる．すなわち，二量体であるなら ば, 平行状態を保つため, 単一成分で保存した場合各分 画はアプロチニンに移行し，Fig. 1 の分析条件におい て，アプロチニンのピークを与えると考えられる. Fig. 4 に, A 社の製品について各分画を分取, 脱塩, 濃縮 し, 蛋白量 $50 \mu \mathrm{g} / \mathrm{ml}$ の濃度で 2 週間遮光下で保存後のク ロマトグラムを示した. その結果, 分画 1 と 2 は 2 週間 後に拈いてもそれぞれ単一なピークを与え, 分画 3 と 4 はいずれも分画 1 と 2 のピークを与えたが, 分画 1 から 4 のいずれもアプロチニンのピークは与えなかった. 一 方, アプロチニン分画は 1 から 4 のピークのすべてを与 えた。
Table 5. Amino Acid Composition of Aprotinin and Unknown Fractions

\begin{tabular}{lcccccc}
\hline \hline & \multicolumn{7}{c}{ Residues per molecule } \\
Amino acid & 1 & 2 & 3 & 4 & 5 & Ref. \\
\hline Alanine & 6.0 & 6.3 & 5.4 & 5.5 & 6.3 & 6 \\
Arginine & 5.6 & 5.6 & 5.9 & 5.7 & 5.5 & 6 \\
Aspartic acid & 4.6 & 4.6 & 4.8 & 4.3 & 4.6 & 5 \\
Half-cystine & 5.4 & 5.5 & 5.8 & 5.9 & 5.7 & 6 \\
Glutamic acid & 3.3 & 3.2 & 3.3 & 3.4 & 3.2 & 3 \\
Glycine & 5.8 & 5.9 & 5.1 & 6.1 & 5.8 & 6 \\
Histidine & 0 & 0 & 0 & 0 & 0 & 0 \\
Isoleucine & 1.4 & 1.0 & 1.5 & 1.4 & 1.3 & 2 \\
Leucine & 2.1 & 2.1 & 2.1 & 2.1 & 2.0 & 2 \\
Lysine & 3.9 & 3.9 & 4.0 & 4.1 & 3.9 & 4 \\
Methionine & 0.8 & 0.9 & 1.0 & 1.0 & 1.0 & 1 \\
Phenylalanine & 4.0 & 3.9 & 4.1 & 4.0 & 3.9 & 4 \\
Proline & 5.1 & 4.7 & 5.5 & 5.0 & 5.1 & 4 \\
Serine & 1.1 & 1.1 & 1.1 & 1.1 & 1.0 & 1 \\
Threonine & 3.0 & 3.1 & 3.1 & 3.2 & 3.0 & 3 \\
Tryptophane & 0 & 0 & 0 & 0 & 0 & 0 \\
Tyrosine & 3.9 & 3.8 & 3.9 & 4.0 & 3.9 & 4 \\
Valine & 1.0 & 0.9 & 1.1 & 1.0 & 1.0 & 1 \\
& & & & & & \\
\hline & & & & & \\
\hline
\end{tabular}

これらのことは, 分画 1 から 4 は二量体であることは 否定されたが，アプロチニン由来の成分であることが考 えられた。また，その生成過程は，アプロチニンから不 可逆的もしくは平衡が極端にずれて括こると考えられ た。

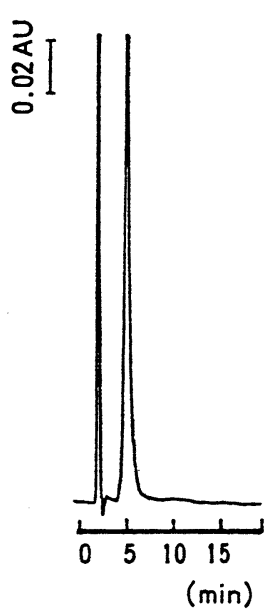

Fraction 1

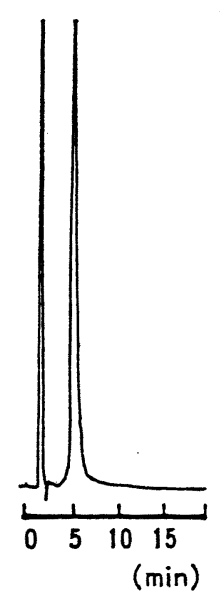

2

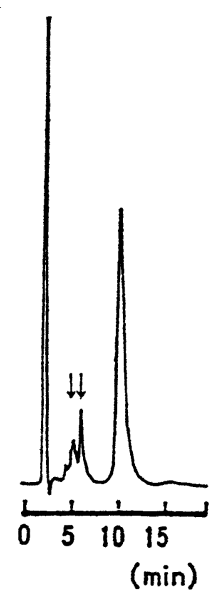

3

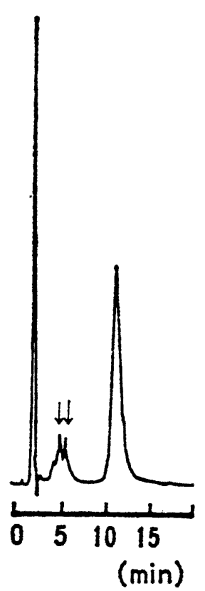

4

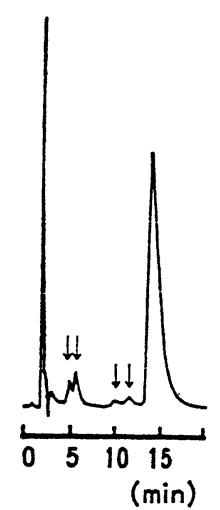

5

Fig. 4. Chromatograms of Aprotinin and Unknown Fractions after Two Weeks Preservation 


\section{文献}

1）高杉益充，梅田貴文，服部暁昌，京谷庄二郎，庄 野交章, 水口和生, 宮田一好 : 病院薬学, 8, 129 (1982).

2) B. Kassel: Meth. Enzym., 19, 844 (1970).

3) Lowry, O.H., Roserbrough, N.J., Farr, A. L., and Randall, R. J. : J. Biol. Chem., 193, 265 (1951).

4）笹川 立, 千谷晃一: 蛋白質核酸酵素, 127,1056
(1982)

5) 中沢宏, 長瀬正之: 薬学雑誌, 106, 398(1986).

6) M. Gazdag, G. Szepesi: J. Chromatogr., 218, 603 (1981).

7) A. Nakum, C.Horvath: J. Chromatogr., 203, 53 (1981).

8）バイェル薬品侏社内資料：HPLCによる他社製品 との品質比較

9) I. Trautschold: Habilitationsschrift der Med. Fakultat, Munchen, 1965.

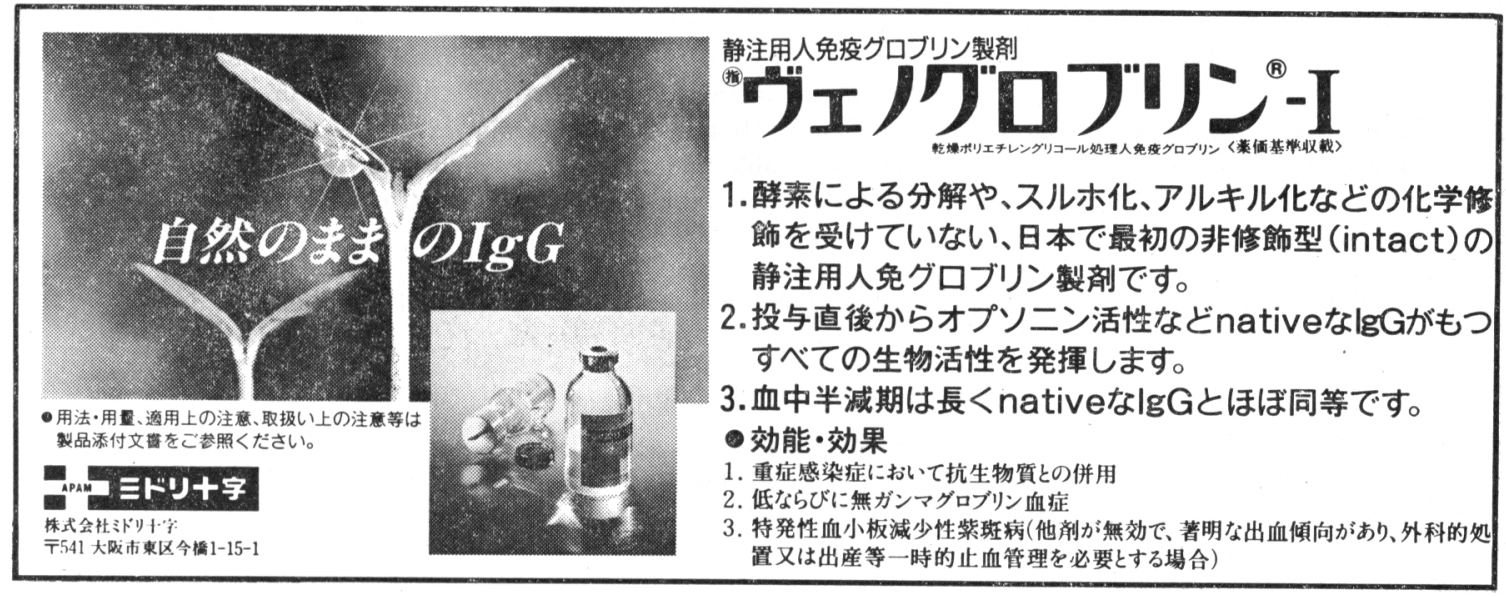

